\title{
Local economic development initiatives from the bottom-up: the role of community development corporations
}

\author{
Flaminio Squazzoni
}

\begin{abstract}
This paper deals with the pivotal role played by community development corporations (CDCs) in local economic initiatives from the bottom-up. These non-profit organizations are challenging the top-down approach of political decision making, mobilizing community assets, connecting inside and outside resources, synthesizing visions, expertise and methods from private, public and community sectors. In doing so, they are demonstrating the relevance of non-profit organizations and institutions in fostering social capital and promoting collective action across different sectors and actors. To illustrate these arguments, this paper has reported two case studies of local economic development initiatives in North America that are centered on two CDCs. The positive effects and critical points of CDCs have been addressed.
\end{abstract}

\section{Introduction}

In the globalization era, local communities and regions are called on to play a front line role in mobilizing internal and external assets to establish economic development initiatives from the bottom-up (Robinson, 1995; Babacan and Gopalkrishnan, 2001; Leeming, 2002; McCall, 2003). This is what Kretzmann and McNight (1993) called 'asset-based community development'. This new approach closely rediscovers what Albert O. Hirschman argued more than fifty years ago, that is, that economic development does not merely depend on the optimal combination of given resources or production factors, but rather on finding and mobilizing hidden and 
under-utilized capabilities and assets on the ground, step by step, searching for bottom-up complementarities (Hirschman, 1958).

This paper aims to understand the reasons why community development corporations (CDCs) are taking growing responsibility and authority on such bottom-up local development initiatives in North America. The first section shows the difference between corporate businesses, government institutions and CDCs, focusing in particular on governance structures and organizational principles. Although there is no common definition of a CDC, this section attempts to outline the most important features of these organizations. The second section introduces two case studies of development initiatives in two North American communities. The final section summarizes the main findings of the paper and makes some critical remarks.

\section{CDCs as carriers of local economic initiatives}

There is a broad agreement that community organizations, in particular CDCs, are playing an increasingly pivotal role in mastering and fostering local economic development initiatives by bringing corporate business, civic organizations and public agencies into concrete collaborations (Austin, 2000; Bradshaw, 2000; Sagawa and Sega, 2000; Silverman, 2001; Blaxter, Farnell and Watts, 2003). Typically, the purpose of these initiatives is to produce a set of highly specialized public goods, such as, the improvement of human and social capital in communities, or knowledge and technology transfer across sectors (Henton, Melville and Walesh, 2004). This is accomplished by the commitment and involvement of different stakeholders (e.g. producers, beneficiaries and philanthropists) belonging to different socio-economic sectors and able to share time, knowledge, money and expertise within project-oriented partnerships built around long-term visions and commonly recognized goals. In this collaboration, CDCs benefit from being perceived as community agencies capable of endorsing the goals of community stakeholders and, as a consequence, are often viewed as suitable collaboration platforms (Mendel, 2003).

The organizational outline of the community-based non-profit sector has two levels: 'informal' organizations, such as neighborhood associations or grassroot associations, and "formal" organizations, such as CDCs (Green and Haines, 2002). The first level embraces a plethora of autonomous local associations, small with few staff, minimal structure, a weak hierarchy and voluntary horizontal membership. These associations benefit from a strong community identity, the sharing of social experience, voluntarism and an attitude towards the reciprocity of community members. They emerge around particular and challenging collective problems that can be solved locally (Kelly and Caputo, 2006). They are often created and die 
quickly (Smith 1999a, 1999b). The second level includes organizations with a more stable and articulated structure based on professionals, with a managerial culture, and large-scale visions and goals. These organizations operate on the financial markets by combining mixed sources of funding and investing financial and human resources in economic community development initiatives, with a strong focus on measurements, methods and outcomes, as well as on the capitalization of economic and social investments.

Unlike corporate business, CDCs have a governance structure directly open to community leaders, interests and institutions and embedded into the social context. They have the capacity to take high-risk initiatives even in the absence of secure financial returns. They aim to generate positive externalities on other players and initiatives in the community. They are capable of producing local public goods, strengthening social capital and collective action within the communities. Like corporate businesses, they operate in financial markets, they have a lot of professionals, they use reputation to attract financial resources, they act in a managerial perspective and they make extensive use of evaluation, control and monitoring tools and methods, such as reports, technologies and marketing strategies.

Unlike public government institutions, CDCs have the following peculiarities: they are independent organizations, with an agile and flexible style of doing things, are strongly embedded in their communities, pursue a new approach to citizenship based on commitment, empowerment and participation, include community members in the decision-making process and in initiatives, they require direct participation and voluntary commitment to people, but offer in return a reduced 'delegacy' in decision making and authority and are embedded in a web of relations with other community associations, such as neighborhood and grassroots associations (Hughey, Speer and Peterson, 1999). Like public institutions, they have public goals, they are policy makers in all respects, but they can overcome those typical information asymmetries that penalize public institutions when they set up social and public services, which were rightly emphasized in the famous Weisbrod's argument (Weisbrod, 1988).

\section{Two case studies}

To evaluate the pivotal role that CDCs can play in launching and managing local development initiatives across sectors, two case studies have been briefly introduced. The first one is the 'Fruitvale BART Transit Village Initiative' in Oakland, California, where, thanks to the strength of a local $\mathrm{CDC}$, the re-engineering of a transport infrastructure was given a chance to re-design political participation and traditional decision making and 
involve the local community in economic development initiatives. The second one focuses on a set of economic development initiatives undertaken in the Maine region.

\section{Case study I}

The Fruitvale BART Transit Village Initiative is a broad partnership among public, private and nonprofit organizations working together to revitalize a community in Oakland, California, which was disadvantaged by a number of economic and social problems. Oakland is the sixth city of California. Situated on the eastern area of San Francisco Bay, it has a population of 395,000 , with a majority of African-Americans and whites (43 percent). Fruitvale is an Oakland neighborhood of 53,000 that earned its name when German settlers immigrated to the area to plant fruit orchards. It has over ninety percent minorities, as summarized in Table 1.

Until the 1950s, Fruitvale was a prosperous neighborhood, with a lot of business activity. Fruitvale's problems date back to the 1950s, when the construction of new freeways created opportunities for manufacturing firms and a new middle class began to localize outside the area. In the 1960s, Fruitvale became a depressed area, even if it retained a number of significant assets, such as an important railway station and a strong network of non-profit organizations and civic associations.

A focal node of such associational tissue was the Unity Council, a CDC with strong ethnic reference, founded in 1964 by Arabella Martinez, Assistant Secretary of the US Department of Health, under the name of 'The Spanish Speaking Unity Council'. The Unity Council became in all respects a non-profit organization in 1968, with the aim of promoting community initiatives to improve the environmental, economic and social quality of community life, such as development of affordable housing, business assistance, job readiness and employment services and cultural initiatives (CDC Oral History Project, 2003).

Table 1. Data on Fruitvale neighborhood (1990 US Census)

\begin{tabular}{lc}
\hline Localization & $\begin{array}{c}\text { Downtown Oakland, } \\
\text { Southeast area }\end{array}$ \\
\hline Population & 53,000 \\
Racial and ethnic composition (percent) & 52 \\
Latino & 23 \\
Asian/Pacific islanders & 16 \\
African-American & 7 \\
White & 2 \\
Native American & 1 \\
Others & 1 \\
\hline
\end{tabular}


The Fruitvale Village project was created in June 1991, first as an informal opposition to the BART (Bay Area Rapid Transit District) plan to build a multi-level parking facility adjacent to the station. The basic assumption of the BART plan was that the Fruitvale crisis was mainly dependent on its inability to encourage consumption by station users and to connect the station with commercial activities. The community opposed this on the grounds that such an initiative would cause several negative externalities on its quality of life, such as the split between commercial and residential neighborhoods, increased crime, traffic congestion and environmental problems. In a word, the parking facility would not be an appropriate answer to economic and social needs of the community (Snow, 2001).

The Unity Council decided to lead the community opposition, starting to defend it against local and national political authorities under the principle that revitalization initiatives at a local level should directly involve the community in the evaluation and decision-making processes. Thus, the usual information asymmetries of community needs between decision makers, technicians and residents would be reduced, as well as new ideas and solution explored. The proposal of the Unity Council was to consider the local community as a knowledge bearer, a repository of fundamental competences and a source of ideas and intuitions to be exploited.

In February 1992, thanks to social embedding, reputation and acquired authority, the Unity Council was allowed by the City of Oakland in Community Development Block Grant Funds to initiate a community planning process to understand how to revitalize the area appropriately. The Unity Council began to organize a series of workshops and meetings with different community stakeholders, namely civic associations, neighborhood associations, businesses, professionals, representatives of local institutions, local non-profit organizations and residents. From these first workshops, after further funds from US DOT in 1993 and a set of economic, traffic and engineering studies on the area, the idea emerged of organizing a community design symposium. Architects began to work together with community representatives to translate ideas and intuitions in the feasible projects. After several community meetings, a more restricted decisionmaking unit was founded, under the name of 'Facade Improvement Design Committee', composed of community residents, architects and planning experts. In July 1994, Unity Council, BART and City of Oakland signed a memorandum of understanding and formed the Fruitvale Policy Committee to foster financial, organizational and law synergies.

In 1995, the Unity Council organized a series of community site planning meetings to help stakeholders to find an agreement about plans. Participants identified crime, lack of retail business and community services, the negative image of the area and the lack of connection between the 
station and the community as strategic issues to be dealt with and as problems to be solved. Other issues to be taken into account were job creation, quality of the environment, the availability of rental services in the community as well as affordable housing.

After these meetings and some final technical studies, the Unity Council established the Fruitvale Development Corporation to manage the implementation of these initiatives. Fruitvale Development Corporation is a non-profit public benefit corporation with representatives from local associations, foundations and corporate businesses involved in the project as its main stakeholders. The mission is two fold: enlarging the social impact of the initiative, trying to use the re-engineering of the infrastructure as a chance for solving community problems, and at the same time, keeping the initiative feasibility under control, managing its multiple objectives (Martinez, Cohen and O'Hare, 2002).

The initiative finally entered into action. As is summarized in Table 2, originating from the old transportation infrastructure and the BART original parking plan and thanks to the Unity Council, wide participation and community decision making, the result was a new infrastructure on 19 acres, creating 700 new jobs (including several new professions) and about $\$ 150$ million of investment. These included a set of public, economic and social services, with La Clinica de La Raza's modern community health clinic, a child development center, senior and family housing and the Cesar Chavez Public Library. This meant a set of activities that allowed the transformation of traffic on the broad scale of community change, with an important effect on the local labor market, advantages both for residents and users, in a traffic area that counted 15,000 everyday users (O'Hara, 2001; Owen, 2002). The connection between the station and the East 12th Street commercial district, through a new pedestrian area, allowed the revitalization of neighborhood commercial activities and more outside consumers. The municipality benefited from the success of the initiative, above

Table 2. Composition of Fruitvale Transit Village (US Department of Transportation, 2003)

\begin{tabular}{ll}
\hline Retail/restaurant use & $45,000 \mathrm{ft}^{2}$ \\
\hline Non-profit health-care clinic & $55,000 \mathrm{ft}^{2}$ \\
Child care facility & $55,000 \mathrm{ft}^{2}$ \\
Library & $15,000 \mathrm{ft}^{2}$ \\
Executives offices & $45,000 \mathrm{ft}^{2}$ \\
Units of housing & 68 \\
Units of mixed-income housing & 220 \\
Parking garages for I500 cars & 2 \\
\hline
\end{tabular}


all thanks to new knowledge about participative decision making and best practices to be exploited in other initiatives.

\section{Case study II}

The Maine Fisheries Project is a multi-faceted initiative to revitalize the fishing industry in the Maine region, established by Coastal Enterprise Inc. (CEI), a local CDC, in 1994. CEI was founded in Wiscasset, Maine in 1977 (Table 3). From its foundation, the CEI mission was to improve the quality of economic and social development in the region. This was done with the following initiatives: providing financing and supporting jobcreating small businesses in the fishing industry, guaranteeing technical and financial services, promoting employment, diffusing the economic advantages of business to community, developing research projects for new products and fostering the implementation of new technologies on management and organizational processes, strengthening collaboration scaffolds between scientific research and industrial applications and finally, guaranteeing development and reproduction of natural resources in the Maine region. To support local financial investments, CEI applied a venture capital model, based on diversification of financial assets and sources, a strategic marketing approach, close attention to communication and reputation, and a managerial approach to innovation projects (Jegen, 1998).

As is summarized in Table 4, the fishing industry is an important asset for the State of Maine, with an estimated number of more than 10,000 of both part-time and full-time fishermen, 26,000 jobs in the commercial sector and about $\$ 777$ million of average value for the whole industry per year. In the early 1990s, this industry suffered from strong competitive pressure, with subsequent negative effects on 26,000 employees, in terms of price reduction in goods and a drastic shrinkage of demand (CEI, 2004a).

The Maine Fisheries Project created by CEI is a good example of an integrated approach to environmental, economic and social sustainable

Table 3. Data on CEI on 2002 (CEI, 2002)

\begin{tabular}{ll}
\hline Staff & 92 people \\
\hline Loans/investment outstanding & 571 \\
Capital under management & $\$ 107$ million \\
Businesses financed & 1310 \\
Loan dollars invested & $\$ 108$ million \\
Jobs created and maintained & 15,000 \\
Affordable housing units created & 526 \\
Firms or people counseled & 15,000 \\
\hline
\end{tabular}


Table 4. Data on the fishing industry in Maine updated in 2003 (CEI, 2004a)

\begin{tabular}{ll}
\hline Estimated average value of the & $\$ 777$ million per year \\
Maine fishing industry & \\
\hline Average catch in 2000 & 328.8 million \\
Catch average weight per year in the area & 256.8 million of Libra \\
Value compared with other areas & In $2000-2003$, in fishing, Maine is ranked first \\
& in the Northeast areas for catch and added \\
& value. Portland is ranked third in Northeast \\
& and ninth at a national level \\
Jobs in the commercial sector & 26,000 \\
Fish species & 70 \\
Number of permits in 2000 & 18,000 \\
Estimated number of full-time fishermen & 6000 \\
Estimated number of part-time fishermen & 4300 \\
Value of lobster fishing in 1999 & 184.6 million \\
\hline
\end{tabular}

development and demonstrates how community economic development can succeed on a systemic scale. CEI strategies conform to what Kretzmann and McNight (1993) called an asset-based community development strategy. First, it maps existing and hidden community assets. Second, it mobilizes, coordinates and makes them complementary and effective for community development. These assets referred initially to a vast number of individuals working in the fishing industry who demonstrated their commitment to participate in community development projects as volunteer boards with a strong responsibility for initiatives. Then, relevant assets such as knowledge, direct commitment, ideas and intuition came from workers, fishermen's families and directly involved local businesses. Other relevant assets came from a web of entrepreneurial associations, research centers and businesses networks that CEI attracted with the aim of developing strategic initiatives to re-define markets, identify new products and promote technology investment. Finally, a vast amount of financial, human, knowledge and scientific resources came from within both CEI and its network and community, which included philanthropic foundations, banks, corporate businesses, political institutions and professional associations.

One of the best tools elaborated by CEI was the so-called 'Fishtag', founded in 1999. Fishtag was a successful attempt to institutionalize a mechanism for regulating the transactions and partnerships among all players involved in research and applied industrial projects, such as entrepreneurs, consumers and researchers, with the aim of fostering information sharing, scientific knowledge creation and diffusion and community management, through a series of formal agreements regulating access to 
funding. CEI offered Fishtag partners financial, technical and organizational services. Between 1999 and 2003, Fishtag projects grew by 53 percent, with a total amount of 32 outstanding projects. They generated $\$ 2.6$ million of financial investments (plus \$3.8 million from CEI investment and debt), created 95 new jobs and involved more than 70 fishermen and representatives of the fishing industry. It is calculated that the research projects had a strong impact on the area in terms of innovation and returns on investment (CEI, 2003).

The science-industry collaboration under Fishtag also discovered new potential market niches, new market segmentation, process and technology innovation, new educational programs for young, women and workers in the region, with a reduction of the critical mismatch between competencies needed by the market and people's competencies (Sheenan and Cowperthwaite 2002; CEI 2004c).

The positive externalities of the Maine Fisheries Project on market labor and entrepreneurship in the Maine region are summarized in Table 5. The financial side of success was due to the adoption of a venture capital approach. Financial institutions appreciated the presence of an organization, such as CEI, that was capable of allocating economic and human resources on risky long-term initiatives in a socially responsible way. This was in order to generate measurable social and economic returns, to trigger significant social impacts and at the same time, to strengthen its organizational capabilities, thus reinforcing its role as a pivot for the development of effective projects in the area.

\section{Concluding remarks}

As Knotts (2006) emphasized, we are still far from measuring and understanding fully the effects of CDCs on community development, or drawing lessons from particular case studies to be generalized on a broad scale. Moreover, community development analysts are divided over the

Table 5. Impact of CEI and Maine Fisheries Project on the fishing industry in Maine (CEI, 2004b)

\begin{tabular}{ll}
\hline Amount of funding in Maine Fisheries Project & $\$ 31.5$ million \\
\hline $\begin{array}{l}\text { Number of loans to businesses in the } \\
\text { fishing sector }\end{array}$ & 133 \\
$\begin{array}{l}\text { Impact of Maine Fisheries Project on the local } \\
\text { labor market }\end{array}$ & 1115 full time jobs and 224 part-time jobs \\
$\begin{array}{l}\text { Average salary per hour in new jobs } \\
\text { Use of loans/investments by businesses }\end{array}$ & $\begin{array}{l}\$ 10 \text { per hour, benefits excluded } \\
39 \text { start-ups; } 36 \text { industrial restructuring; } 58 \\
\text { expansion projects }\end{array}$ \\
\hline
\end{tabular}


positive or negative effects of CDCs. Some emphasize that CDCs tend to subordinate themselves to commercial interests, that they cannot fully grasp and interpret the conflicting nature of community voices and the ambivalence of the community with its conservative and progressive potential, or that they are not always able to build strong ties with the plethora of community associations, from which community opinions and leaders arise. On the other hand, others emphasize the capacity of CDCs to generate social capital and to foster collective action in communities by connecting methods and approaches from different sectors. At the same time, everyday globalization implies a set of challenges and dilemmas for the societal functions of CDCs and for the relevance of the community as a locus of political, social and economical change in an unpredictable scenario (Bratt and Rohe, 2007; Shaw, 2008).

In this respect, the case studies introduced in this paper allow us to emphasize the positive side of the coin, but also some critical points. First, the two stories address very different initiatives. The Fruitvale initiative is embedded on a very local scale, whereas the Maine Fisheries Project addresses a socioeconomic challenge at a region level. The latter highlights recent changes in the range and functions of CDCs, which are not only interested in neighborhood issues or affordable housing initiatives, but also in coping with broad socio-economic challenges. The first case study allows us to appreciate the policy-making function that a CDC can play if it is able to lend an ear to and endorse community voices. The second allows us to appreciate the relevance of CDCs in generating collaborative frameworks and specific collective action institutions across public, private and community sectors to solve very complex and integrated development problems.

Second, the success of the initiatives was influenced by a socially shared community threat line and by some positive contingent factors as well. In the Fruitvale village case, the threat was an unpopular public plan that mobilized the community voice. On the other hand, success mostly rested on the intuition of local government institutions in stepping-back from leadership and decisions, and in supporting the initiative, and on the capability of the Unity Council to endorse, manage and expedite the community voice. At the same time, the Unity Council pursued a strategy of using this initiative to redefine its target, that is, to become a CDC to all intents and purposes, and not only a 'Spanish speaking' organization. Although it benefited from an alignment of interests of all the players involved, which is not always the general rule in community activity, the Unity Council continually looked to involve community associations, leaders and residents in each step of the initiative and above all to reduce information asymmetries between planners, technicians and citizens to find a collective way towards innovation. 
In the Maine Fisheries Project case, the threat was an economic crisis perceived by all participants in the fishing industry. The contingent factor was the promptness of people to defend local identity, capabilities and products against the globalization challenge. Success was strongly dependent upon the capability of the CEI to create a collaboration framework to support inter-sector initiatives, and in particular, to create specific institutions (such as Fishtag) and other initiatives that have helped players to regulate collaboration and knowledge externalities.

Third, there are also some critical points to be raised. Both cases call for the burning question of how corporate players can decide on public domain issues, since it is unlikely that they can represent universal interests. As a matter of fact, the authority of corporate players, such as CDCs that speak for public interest, comes from direct involvement and power and not from democratic 'delegation'. Without entering into a debate on the benefits and dangers of interest associations and private governments or mirror the debate on the crisis of democratic institutions in the era of globalization (e.g. Streeck et al., 2006), it is without doubt that CDCs have hit this nerve.

The main theoretical finding from the two cases is that, those initiatives would not have been possible either from market incentives and motivations, or to top-down public government authority. As is well known, non-profit organizations such as CDCs can often act to reduce information asymmetries between investors and beneficiaries, to foster collective action frameworks by generating social capital and effectively to align the goals of people involved in the production of public goods (Weisbrod, 1997; Deshi, 2000; Mubangizi, 2003). The capability of the Unity Council and CEI to generate social capital allowed the communities to tap important social and economic resources in order to support their initiatives, both inside and outside the communities, including funding, the commitment of individuals and associations, capabilities, time, trust and positive expectations. All of this would have been impossible by means of market or state mechanisms, i.e. by playing on private interest and individual profit-oriented motivation or by using top-down traditional political institutions (Dasgupta, 2000).

In the best case scenario, CDCs can benefit from their capacity of generating and managing inter-sector partnerships, from a mix of public vocation goals and organizational managerial methods (Carman, 2001 and Von Hofmann, 2001) and from their horizontal and participative governance structures. Moreover, they can benefit from being socially embedded, their capacity of producing social capital and collective mobilization, their cultural roots in communities, their capacity of combining social and economic objectives, by producing social services, goods and capitalizing, and at the same time financial, organizational and human resources (Lenzi, 1992; Jegen, 1998; Sullivan, 1998; Van Auken, 2002). 
Such a double bottom-line is particularly evident in the case study on CEI. This case study indicates that CDCs can fruitfully combine the production of public goods with the need for capitalizing financial and human resources, applying scientific methods of project management and monitoring and evaluating outcomes. The latter are the most significant levers to attract private capital for social initiatives. On this, the CEI case study conforms to what Henton, Melville and Walesh (2004) defined 'civic entrepreneurship' and 'regional stewardship'. In this sense, the entrepreneurial spirit, method and vision typical of economic spheres are applied to social purposes and dedicated to strengthen community vision, empowerment and capabilities (Community Wealth Ventures, 2002). Examples of this kind are essential to look for positive integration and collaboration between the economy and society (Waddell, 1995; Hautekeur, 2005), as well as to transform the old tradition of giving (just money and not strategic commitment) that has been established by twentieth century philanthropic institutions (Tracey, Phillips and Haugh, 2005).

In conclusion, it is worth noting that one could find that the two case studies over-represent the positive aspects of CDCs, even if some critical points have been mentioned. CEI and the Unity Council can be viewed as examples of high profile and excellent CDCs. Most CDCs are not prepared to cope with globalization challenges given that most of the problems addressed are due to national or international factors (Bratt and Rohe, 2007). But, unlike the average CDCs in North America, with 6-7 full-time employees and 19 in total, little annual funds and specializing in affordable housing, the Unity Council and CEI are two exceptional cases (Vidal, 1997; Von Hoffman, 2001). In a sense, their excellence comes from the fact that they demonstrate the potential of the CDC return to more challenging socioeconomic initiatives, after their retreat into less risky investment areas, under the motto 'housing first', before the 1990s (Vidal, 1997; Von Hoffman, 2001). Such excellence does not debase the relevance of the lessons we can learn from these case studies. At the same time, a debate on the consequence of the growth of these corporate organizations for public domain issues, on their effective capability to encourage community participation and leadership and on their inclusiveness towards plural and universal interests should absolutely be made.

\section{Acknowledgements}

I would like to express my gratitude to the following colleagues and community development practitioners who have enriched my work with help, information, remarks and suggestions: Tom Dewar, Alison Mathie, Gord Cunningham, John Kearney, Manuela Silva (senior executive of Unity 
Council), Soo Zee Park and Tom Limon (Unity Council), Elizabeth Sheehan (past director of Coastal Enterprises, Inc. and manager of Maine Fisheries Project). A special thanks go to John McNight, John Kretzmann, Deborah Puntenney and Sarah Dobrowolski (ABCD Institute, Northwestern University) for their help and inspiration. Giuliana Gemelli and her post graduate students of MISP (Master in International Studies in Philanthropy and Social Entrepreneurship), University of Bologna, Italy, have enriched a preliminary version of this paper with remarks and suggestions. Finally, I would like to thank an anonymous referee for remarks and suggestions. Usual disclaimer applies.

\section{Funding}

This work acknowledges financial support by Cariplo Foundation, Italy.

Flaminio Squazzoni is assistant professor of Economic Sociology at Department of Social Sciences, University of Brescia, Italy

Address for correspondence: Dipartimento di Studi Sociali, Università di Brescia, Via San Faustino 74/B, 25122 Brescia, Italy; email: squazzon@eco.unibs.it

\section{References}

Austin, J. (2000) The Collaboration Challenge. How Nonprofits and Business Succeed Through Strategic Alliances, Jossey-Bass, San Francisco.

Babacan, H. and Gopalkrishnan, N. (2001) Community work partnerships in a global context, Community Development Journal, 36 (1), 3-17.

Blaxter, L., Farnell, R. and Watts, J. (2003) Difference, ambiguity and the potential for learning-local communities working in partnership with local government, Community Development Journal, 38 (2), 130-139.

Bradshaw, T. G. (2000) Complex community development projects: collaboration, comprehensive programs, and community coalitions in complex society, Community Development Journal, 35 (2), 133-145.

Bratt, R. G. and Rohe, W. M. (2007) Challenges and dilemmas facing community development corporations in the United States, Community Development Journal, 42 (1), 63-78.

Carman, J. G. (2001) Community foundations. A growing resource for community development, Nonprofit Management E Leadership, 12 (1), 7-24.

CDC Oral History Project (2003) Spanish Speaking Unit Council, PICCED Pratt Center for Community and Environmental Development.

CEI (2002) 2002 Annual Report, Report.

CEI (2003) FISHTAG Report, Report.

CEI (2004a) Fisheries Project, Report.

CEI (2004b) CEI's FISHTAG Project, Report. 
CEI (2004c) CEI's Fisheries Research and Development Projects, Report.

Community Wealth Ventures, Inc. (2002) Venture Philanthropy 2002. Advancing Nonprofit Performance Through High-Engagement Grant Making, Report.

Dasgupta, P. (2000) Economic progress and the idea of social capital, inDasgupta, P. and Serageldin, I. eds, Social Capital: A Multifaceted Perspective, World Bank Publications, Washington.

Deshi, A. S. (2000) Social capital and community development, Community Development Journal, 35 (3), 199-214.

Green, G. P. and Haines, A. (2002) Asset Building and Community Development, Sage Publications, Thousand Oaks, London, New Delhi, India.

Hautekeur, G. (2005) Community development in Europe, Community Development Journal, 40 (4), 385-398.

Henton, D., Melville, J. and Walesh, K. (2004) Civic Revolutionaries. Igniting the Passion for Change in America's Communities, Jossey-Bass, San Francisco.

Hirschman, A. O. (1958) The Strategy of Economic Development, Yale University Press, New Haven.

Hughey, J., Speer, P. W. and Peterson, A. (1999) Sense of community in community organizations: structure and evidence of validity, Journal of Community Psychology, 27 (1), 97-113.

Jegen, D. L. (1998) Community development venture capital. Creating a viable business model for the future, Nonprofit Management \& Leadership, 9 (2), 187-200.

Kelly, K. and Caputo, T. (2006) Case study of grassroots community development: sustainable, flexible and cost-effective responses to local needs, Community Development Journal, 41 (2), 234-245.

Knotts, H. G. (2006) Sticks, bricks, and social capital: the challenge of community development corporations in the American deep South, Community Development Journal, 41 (1), 37-49.

Kretzmann, J. P. and McNight, J. L. (1993) Building Communities from the Inside-out. A Path toward Finding and Mobilizing a Community's Assets, Acta Publications, Chicago.

Leeming, K. (2002) Community businesses-lessons from Liverpool, UK, Community Development Journal, 37 (3), 260-267.

Lenzi, R. C. (1992) Nontraditional sources of economic development financing, Economic Development Review, 10 (3), 20-23.

Martinez, A., Cohen, P. H. and O'Hare, S. (2002) Partnerships, Enhancements, and Public Involvement, US Department of Transportation, Environmental Justice, Case Studies.

McCall, T. (2003) Institutional design for community economic development models: issues of opportunity and capacity, Community Development Journal, 38 (2), 96-108.

Mendel, S. C. (2003) The ecology of games between public policy and private action, Nonprofit Management $\mathcal{E}$ Leadership, 13 (3), 229-236.

Mubangizi, B. B. (2003) Drawing on social capital for community economic development: insights from a South African rural community, Community Development Journal, 38 (2), 140-150.

O'Hara, S. U. (2001) Urban development revisited: the role of neighborhood needs and local participation in urban revitalization, Review of Social Economy, LIX (1), 23-43. 
Owen, S. (2002) From village design statements to parish plans: some pointers towards community decision making in the planning system in England, Planning Practice $\mathcal{E}$ Research, 17 (1), 81-89.

Robinson, M. (1995) Towards a new paradigm of community development, Community Development Journal, 30 (1), 21-30.

Sagawa, S. and Sega, E. (2000) Common interest, common good: creating value through business and social sector partnerships, California Management Review, 42 (2), 105-122.

Shaw, M (2008) Community development and the politics of community, Community Development Journal, 43 (1), 24-36.

Sheenan, E. and Cowperthwaite, H. (2002) Preserving Commercial Fishing Access: A Study of Working Waterfronts in 25 Maine Communities, CEI Report.

Silverman, R. M. (2001) Neighborhood characteristics, community development corporations and the community development industry: a case study of the American deep South, Community Development Journal, 36 (3), 234-245.

Smith, D. H. (1999a) The effective grassroots association. I. Organizational factors that produce internal impact, Nonprofit Management \& Leadership, 9 (4), 443-456.

Smith, D. H. (1999b) The effective grassroots association. II. Organizational factors that produce external impact, Nonprofit Management E Leadership, 10 (1), 103-116.

Snow, L. K. (2001) Community Transformation: Turning Threats into Opportunities, Acta Publications, Chicago.

Streeck, W., Grote, J., Schneider, V. and Visser, J. (Eds) (2006) Governing Interest, Routledge, London and New York.

Sullivan, M. L. (1998) Evaluating the effects of community development corporations on conditions and perceptions of safety, Security Journal, 11, 51-60.

Tracey, P., Phillips, N. and Haugh, H. (2005) Beyond philanthropy: community enterprise as a basis for corporate citizenship, Journal of Business Ethics, 58, 327-344.

US Department of Transportation (2003) Land Use Success Story. Fruitvale BART Transit Village, Report.

Van Auken, H. (2002) A model of community-based venture capital formation to fund early-stage technology-based firms, Journal of Small Business Management, 40 (4), 287-301.

Vidal, A. C. (1997) Can community development re-invent itself? Journal of The American Planning Association, 63 (4), 429-438.

Von Hoffman, A. (2001) Fuel Lines for Urban Revival Engine. Neighborhoods, Community Development Corporations, and Financial Intermediaries, Fannie Mae Foundation, Practice Report.

Waddell, S. J. (1995) Emerging social-economic institutions in the venture capital industry: an appraisal, American Journal of Economics and Sociology, 54 (3), 323-338.

Weisbrod, B. A. (1988) The Nonprofit Economy, Harvard University Press, Cambridge, Massachusetts.

Weisbrod, B. A. (1997) The future of the nonprofit sector: its entwining with private enterprise and government, Journal of Policy Analysis and Management, 16 (4), 541-555. 